\title{
GERAKAN LITERASI SEKOLAH PADA MATA PELAJARAN SEJARAH UNTUK MENINGKATKAN HASIL BELAJAR SISWA
}

\section{SCHOOL LITERACY MOVEMENT IN HISTORY SUBJECTS TO IMPROVE STUDENT LEARNING OUTCOMES}

\section{SARWIYOTO}

SMA Negeri 67 Jakarta

\section{Abstract}

Received: March 09, 2021 The purpose of writing is to determine the increase in student learning outcomes in Indonesian Revised: September 30, 2021 history subjects after the literacy movement carried out in schools. This study uses the Classroom Accepted: November 26, 2021 Action Research Method, starting with pre-cycle activities and then conducting research activities with action cycles 1 and cycle 2 . The results of research in class XI IPS 2 obtained pre-cycle value data from 36 people the average value is: 73.06. Minimum Completeness Criteria Value is 75.00. Furthermore, the value in cycle 1 activities is: 78.66. In cycle 2, learning activities have led to the habituation of literacy activities and exploration of teaching materials. So all students of class XI IPS 2 were completed, with an average score of: 84.72. The conclusion of this paper is that the school literacy movement can improve student learning outcomes in Indonesian history subjects
\end{abstract}

\begin{abstract}
Abstrak.
Tujuan penulisan ini yaitu mengetahui peningkatan hasil belajar siswa pada mata pelajaran sejarah Indonesia setelah adanya gerakan literasi yang dilakukan di sekolah. Gerakan literasi sekolah adalah proses kegiatan yang dilaksanakan di sekolah setelah adanya kebijakan sekolah. Kebijakan sekolah ini kemudian disikapi atau direspon oleh warga sekolah dalam upaya meningkatkan minat baca. Peran guru dalam kegiatan literasi sekolah sangat penting, hal ini dikarenakan guru memegang kendali aktivitas siswa di dalam kelasnya. Penulis mencoba melakukan suatu pemikiaran yang dituangkan dalam suatu tindakan untuk dapat memotivasi siswa dalam meningkatkan kemampuan membacanya sehingga dapat berpengaruh positif pada hasil belajarnya. Menggunakan Metode Penelitian Tindakan Kelas, yang diawali dengan kegiatan pra siklus dan selanjutnya melakukan aktifitas penelitian dengan tindakan siklus 1 dan 2 . Hasil penelitian pada kelas XI IPS 2 diperoleh data nilai pra siklus dari 36 orang nilai rata-ratanya adalah: 73,06. Nilai Kriteria Ketuntasan Minimalnya 75,00. Selanjutnya nilai pada kegiatan siklus 1 yaitu 78,66. Pada siklus 2, kegiatan pembelajaran sudah mengarah kepada pembiasaan aktivitas literasi dan ekplorasi materi ajar. Maka seluruh siswa kelas XI IPS 2 hasilnya tuntas, dengan nilai rata-rata sebesar: 84,72. Kesimpulan dari penulisan ini adalah bahwa gerakan literasi sekolah dapat meningkatkan hasil belajar siswa pada mata pelajaran sejarah Indonesia. Gerakan literasi sekolah selanjutnya dapat dikembangkan pada institusi pendidikan agar dari literasi siswa dapat memiliki pengetahuan, keterampilan dan pembentukan karakter dalam minat baca
\end{abstract}

Keywords: Literacy Movement, History, Resume, and Learning Outcomes.

Kata kunci: $\quad$ Gerakan Literasi, Sejarah, Resume, dan Hasil Belajar.

$\left(^{\star}\right)$ Corresponding Author: $\quad$ sarwiyoto@gmail.com

How to Cite: Sarwiyoto, (2021). Gerakan Literasi Sekolah Pada Mata Pelajaran Sejarah Untuk Meningkatkan Hasil Belajar Siswa. Jurnal Lingkar Mutu Pendidikan, 18 (2), 180-185. https://doi.org/10.54124/jlmp.v18i1.30

\section{PENDAHULUAN}

Bangsa Indonesia menjadi salah satu negara yang memiliki kemampuan literasi rendah di negaranegara Asia, berdasarkan skor dari Programme for International Student Assessment (selanjutnya disingkat PISA) 2018 Indonesia menduduki peringkat negara diatas 70 an. "Selain kemampuan literasi dan matematika, PISA 2018 juga memberikan hasil skor dan pemeringkatan negara-negara The Organisation for Economic Co- Operation and Development (selanjutnya disingkat OECD) " dalam kemampuan sains." (La Hewi, 2020: 64). 
Pentingnya Ilmu pengetahuan dan teknologi sangat berpengaruh pada kemajuan bangsa. Hal ini seperti disampaikan oleh Hasanuddin dalam jurnalnya: "Golongan yang berorientasi pada pola pendidikan modern di Barat pada prinsipnya berpendapat bahwa sumber kekuatan dan kesejahteraan hidup adalah hasil perkembangan ilmu pengetahuan dan teknologi modern yang mereka capai." (Hasanuddin, 2014: 170).

Menjadi masalah bagi kita bahwa ternyata perkembangan kemampuan baca bangsa Indonesia tertinggal. Permasalahan di atas harus segera mendapatkan jalan keluarnya, dan bagaimana ketertinggalan tersebut dapat diupayakan agar kemampuan bangsa Indonesia dapat sejajar dengan negara Asia lainnya. Kementerian Pendidikan, Kebudayaan dan Ristek (KemendikbudRistek) sedang mengupayakan Gerakan Literasi Sekolah (selanjutnya disingkat GLS). GLS menjadi salah satu cara mengembangkan strategi dan diplomasi demi menumbuhkembangkan budi pekerti peserta didik.

KemendikbudRistek mengupayakan gerakan literasi sekolah sebagai prioritas dalam tugas dan fungsinya. GLS dikembangkan berdasarkan sembilan agenda prioritas (Nawacita) yang terkait dengan tugas dan fungsi Kemendikbud, khususnya Nawacita nomor 5, 6, 8, dan 9. Butir Nawacita yang tersebut yaitu: 5) meningkatkan kualitas hidup manusia dan masyarakat Indonesia; 6) meningkatkan produktivitas rakyat dan daya saing di pasar internasional agar bangsa Indonesia dapat maju dan bangkit bersama bangsa-bangsa Asia lainnya; 8) melakukan revolusi karakter bangsa; 9) memperteguh kebinekaan serta memperkuat restorasi sosial Indonesia. (KemendikbudRistek: 2016:1)

GLS tidak hanya dilakukan secara umum, melalui implementasi di perpustakaan atau pada mading sekolah. Namun gerakan ini mengakar sampai dengan kegiatan pembelajaran di setiap mata pelajaran. Penulis mengimplementasikan gerakan literasi pada mata pelajaran sejarah Indonesia untuk mengetahui apakah berpengaruh terhadap hasil belajar pada siswa yang diajarnya. Karena kegiatan literasi tidak hanya pada literasi bidang bahasa, seperti Bahasa Indonesia, dan Bahasa Inggris.

Hakikat literasi sangat terkait dengan bahasa dimana siswa menunjukkan kemampuannya dalam mengidentifikasi, menemukan, mengevaluasi, hal-hal yang dibacanya untuk digunakan dalam menginformasikan dan mengatasi berbagai persoalan yang dihadapi selama penjadi siswa di sekolah. GLS pada mata pelajaran sejarah Indonesia mempunyai makna praktik dalam hubungan sosial terkait pengetahuan, budaya, dan bahasa. Kegiatannya bersifat partisipatif melibatkan seluruh warga sekolah (kepala sekolah, guru, pengawas sekolah, tenaga kependidikan, peserta didik, Komite Sekolah, orang tua/wali murid peserta didik).

Melalui literasi, siswa diharapkan mampu menggali pengetahuan dan ketrampilannya agar menjadi bangsa yang dicita-citakan dalam Undang Undang Dasar 1945. Pada zaman Belanda pendidikan bertujuan untuk menumbuhkan jiwa loyalitas pribumi terhadap penjajah. Pendidikan penjajah yang ditegaskan oleh Snouck Hurgronye bertujuan untuk menumbuhkan jiwa loyalitas pribumi terhadap penjajah Keradjaan Protestan Belanda. Untuk kepentingan tersebut, pelaksanaan sistem pendidikan penjajah tidak luput dari kepentingan divide and rule (pecah belah untuk dikuasai. (Suryanegara: 2015: 310).

Berdasarkan latar belakang diatas, penulis tertarik untuk mengambil judul : Gerakan Literasi Sekolah dapat meningkatkan hasil belajar pada mata pelajaran sejarah Indonesia.

Berdasarkan pada paparan latar belakang masalah diatas, maka perumusan masalah dalam penulisan ini adalah: Bagaimana implementasi gerakan literasi pada mapel Sejarah untuk meningkatkan hasil belajar? Bagaimanakah peran guru dalam kegiatan pembelajaran di kelas pada mata pelajaran sejarah Indonesia?

Tujuan Penulisan yaitu menjelaskan implementasi Gerakan literasi pada mapel sejarah untuk meningkatkan hasil belajar, menjelaskan peran guru dalam kegiatan pembelajaran di kelas pada mata pelajaran sejarah Indonesia.

Definisi literasi dari KemendikbudRistek (2016:2) yaitu suatu kemampuan dalam menyimpan, memahami, dan memakai sesuatu dengan cara cerdas dalam berbagai kegiatan, diantaranya seperti melihat, membaca, menyimak, menulis, dan berbicara. Sedangkan pengertian gerakan literasi sekolah adalah suatu upaya yang dilakukan sekolah yang dituangkan dalam suatu program dan mendapat dukungan dari warga sekolah. Warga sekolah dimaksud adalah siswa, pendidik, tenaga kependidikan, wali siswa, komite sekolah dan pengawas sekolah. 
Membaca adalah suatu proses yang dilakukan serta dipergunakan oleh pembaca untuk memperoleh pesan yang hendak disampaikan oleh penulis melalui media kata-kata/bahasa tulis (Tarigan, 2008: 7). Sedangkan menurut Soedarso (2005: 4) membaca adalah aktivitas yang kompleks dengan mengerahkan sejumlah besar tindakan yang terpisah-pisah, misalnya pembaca harus menggunakan pengertian dan khayalan, mengamati, dan mengingatingat untuk memperoleh informasi dalam bacaan. Menurut penulis sendiri membaca adalah suatu kegiatan kompleks yang melibatkan serangkaian proses ketrampilan dari mata bibir dan mental.

\section{METODE PENELITIAN}

Penelitian ini adalah Penelitian Tindakan Kelas (PTK) yaitu suatu tindakan yang dilakukan oleh pendidik dalam kelas untuk memperbaiki situasi pembelajaran, sebagai inti dari kegiatan pendidikan (Sugiyono 2011: 4). Penulis melakukan Tindakan kelas sesuai dengan jadwal mengajar dan merupakan kegiatan nyata dan terukur. Waktu penelitian dilakukan mulai bulan Agustus 2019 sampai bulan November 2019 atau pada semester ganjil tahun pelajaran 2019/2020. Tempat penelitian di SMA Negeri 67 Jakarta, berlokasi di Jalan Skadron Halim Perdana Kusuma Jakarta Timur. Subyek penelitiannya siswa kelas XI IPS 2 tahun pelajaran 2019/20. Jumlah peserta didik sebanyak 36 orang yang terdiri dari siswa laki-laki 17 orang dan siswa perempuan 19 orang.

Sumber data berupa nilai siswa yang diperoleh setelah diadakan kegiatan pembelajaran dan selanjutnya penulis mengadakan pengambilan nilai pertama (1) nilai yang diperoleh sebelum tindakan atau nilai pra siklus. Kedua nilai yang diambil setelah adanya tindakan pada ulangan siklus I dan nilai yang diambil pada siklus 2. Teknik pengumpulan data dilakukan pada saat proses pembelajaran di kelas berupa observasi langsung terhadap peserta didik dari keaktifan siswa dalam kegiatan pembelajaran, (kehadiran, tertib dalam belajar, berpartisipasi aktif dalam setiap kegiatan) dan aktif dalam mengikuti kegiatan evaluasi pada pra siklus, siklus 1 dan siklus 2.

\section{HASIL DAN PEMBAHASAN}

Kegiatan pembelajaran dimulai dari pra siklus yang dilaksanakan pada senin, 21 Januari 2019, dilakukan sebagai bentuk penjajagan untuk mengetahui kondisi awal siswa sebelum diadakan tindakan atau perlakuan untuk mengetahu hasil belajarnya dengan mengadakan ulangan harian pertama. Selanjutnya setelah diadakan tes awal atau tes ulangan harian diketahui adanya siswa yang mendapatkan nilai yang tidak tuntas. Berdasarkan Kriteria Ketuntasan Minimal dengan standar nilai 75 (tujuh puluh lima) maka diketahui jumlah siswa yang tidak tuntas terdapat 16 orang.

Memperhatikan kondisi kelas tersebut di atas, maka dapat diketahui siswa-siswa yang tidak tuntas dalam ulangan harian pertama pada mata pelajaran sejarah Indonesia. Dengan model pembelajaran saintifik dan penugasan dengan literasi pada mata pelejaran sejarah hendaknya siswa yang tidak tuntas dari ulangan harian pertama diharapkan akan tuntas pada pembelajaran berikutnya.

Kegiatan literasi dalam kelas tidak hanya sekedar membaca dan menulis. namun mencakup bagaimana para siswa dapat menangkap materi pelajaran selama proses pembelajaran sejarah Indonesia berlangsung. Guru berkomunikasi terhadap siswa di kelas dengan penuh kebermaknaan, praktik dalam hubungan sosial yang terkait dengan bahasa, pengetahuan dan budaya. Model pembelajaran dengan pendekatan literasi dalam kelas mengedepankan kecerdasan intelektual, agar literasi yang dibangun dalam pembelajaran di kelas mengandung nilai dan karakter yang perlu dibudayakan pada siswa agar mereka gemar melakukan literasi.

Kegiatan literasi menjadi penting untuk diperhatikan dalam pembelajaran sejarah nasional Indonesia, karena literasi terhadap mata pelajaran sejarah diharapkan dapat merespon siswa untuk senang dalam kegiatan pembelajaran. Pembelajaran melalui literasi akan mendapatkan hasil optimal apabila diberikan dengan berbagai variasi agar siswa tidak jenuh di dalam proses pembelajaran.

Gerakan literasi sekolah merupakan gerakan mewujudkan pembiasaan membaca terhadap siswa dengan cara melakukan kegiatan 15 menit membaca (guru membacakan buku dan warga sekolah membaca dalam hati, sesuai dengan konteks atau target sekolah). Saat pembiasaan membaca terbentuk, selanjutnya diarahkan ke tahap pengembangan, dan pembelajaran (disertai tagihan berdasarkan Kurikulum 2013). 
Tujuan kegiatan literasi yaitu untuk menumbuhkan budaya dan minat membaca siswa. Pernyataan Ditjen Dikdasmen (2016:4) "bahwa kegiatan literasi dilaksanakan untuk meningkatkan keterampilan membaca agar dapat menguasai pengetahuan lebih baik. Materi baca bermuatan nilai-nilai budi pekerti serta kearifan lokal, nasional, dan global yang diberikan sesuai tahap perkembangan siswa".

Profesionalisme guru dalam gerakan literasi pada mata pelajaran sejarah Indonesia merupakan salah satu faktor yang turut berperan dalam usaha meningkatkan hasil belajar siswa. Hal ini dikarenakan guru dapat berperan dalam mengembangkan potensi siswa yang mampu mandiri dan berdedikasi tinggi. Selain itu guru sebagai seorang pendidik yang mempunyai kedudukan sosial atau orang tua kedua setelah orang tua siswa, mempunyai tanggung jawab yang cukup besar bagi perkembangan peserta didiknya.

Kegiatan pembelajaran pada siklus yang akan dilakukan, tentunya tidak terlepas dengan hasil belajar. Pembelajaran saintifik yang didesain terjadi antara pendidik dengan peserta didik, mengarah pada pencapaian tujuan pembelajaran. Adapun tujuan yang akan dicapai dalam kegiatan pembelajaran diantaranya tercapainya atau tuntasnya kompetensi bagi peserta didik, yang mencakup pengetahuan dan keterampilan. Selain itu untuk mendapatkan gambaran ketercapaian hasil pembelajaran. Ketercapaian hasil pembelajaran tersebut dapat dilihat setelah melakukan tes, baik tes lisan maupun tes tertulis. Berdasarkan uraian di atas dapat disimpulkan bahwa diduga terdapat peningkatan hasil belajar sejarah setelah adanya gerakan literasi di kelas XI IPS 2 SMA Negeri 67 Jakarta.

Berdasarkan kajian teori dan kerangka berfikir, maka diduga terdapat peningkatan positif terhadap hasil belajar sejarah Indonesia dengan adanya Gerakan literasi pada siswa di SMA Negeri 67 Jakarta. Dalam penulisan ini, ada paparan dengan dua alur kegiatan, antara lain pelaksanaan literasi pada jam belajar dan pada jadwal yang ditentukan sekolah. Pelaksanaan literasi pada saat jam belajar dilakukan setelah proses pembelajaran dan waktunya setelah melaui metode inti seperti: diskusi, tanya jawab dan lainnya kemudian dilanjutkan dengan literasi.

Kegiatan ini dilaksanakan secara terprogram atau terjadwal. Maksudnya literasi dilaksanakan terjadwal pada jam belajar dan mendapatkan pendampingan oleh guru mata pelajaran pada jam terakhir dengan durasi waktu selama 45 menit. Dalam waktu empat puluh lima menit peserta didik membaca buku bacaan yang dibawanya dan hasil bacaannya dituliskan (dirangkum) pada sebuah lembaran yang disediakan oleh sekolah kemudian ditandatangani guru pendamping. Setelah selesai kemudian dikumpulkan untuk dilaporkan kepada guru bahasa Indonesia yang mengampunya. Selain pada jam belajar didalam kelas, siswa dijadwalkan untuk melakukan kunjungan ke perpustakaan sekolah seperti yang telah dijadwalkan oleh petugas perpustakaan atas rekomendasi wakil kepala sekolah bidang kurikulum. Tujuannya dari kunjungan ke perpustakaan adalah agar siswa dapat memanfaatkan buku-buku diperpustakaan untuk dibaca sebagai bahan referensi materi ajar tambahan.

Penelitian ini dilakukan dengan dua siklus. Siklus I dilakukan pada hari senin 28 Januari 2019. Pra siklus seperti yang diuraikan di atas, adalah untuk mencari data yang digunakan sebagai acuan dalam kegiatan selanjutnya. Data tersebut berupa nilai siswa yang diambil dari pelaksanaan test harian pertama. Pada mata pelajaran Sejarah Indonesia, bahwa nilai ketuntasan kriteria minimalnya adalah 75 (tujuh pulh lima) untuk setiap peserta didik pada tahun pelajaran 2019/2020.

Hasil nilai pada pra siklus diperoleh data sebagai berikut, dari keseluruhan 36 siswa, yang mendapatkan nilai di atas KKM sebanyak 16 orang, sedangkan yang menmperolehkan nilai di bawah KKM sebanyak 20 orang. Nilai rata-rata siswa pada kegiatan penilaian pra siklus adalah: 73,06. Selanjutnya pada kegiatan siklus 1 setelah para siswa diberi tindakan atau dengan melakukan literasi dan meresume materi literasi berkaitan dengan mata pelajaran sejarah Indonesia, seperti yang telah dideskripsikan diatas, maka pada penilain siklus 1 diperoleh data sebagai berikut: Dari jumlah siswa 36 orang, 29 siswa mendapatkan nilai di atas KKM, 7 orang siswa belum tuntas atau mendapatkan nilai di bawah KKM. Sementara nilai rata-rata siswa pada kegiatan penilain siklus 1 yaitu 78,66.

Pada siklus 2 kegiatan pembelajaran sudah mengarah kepada pembiasaan aktivitas literasi dan eksplorasi pada materi ajar dan para siswa tidak hanya sekedar membaca, namun melakukan kegiatan resume pada setiap hasil bacaannya. Sehingga dari kegiatan ini hasil belajar yang dicapai terlihat pada data berikut: dari 36 orang siswa seluruhnya mendapatkan nilai diatas KKM dengan nilai ratarata sebesar 84,72. Dengan demikian seluruh siswa kelas XI IPS 2 dinyatakan tuntas. 
Tabel 1. Analisis Nilai Ketuntasan pada pra siklus, siklus 1 dan 2.

\begin{tabular}{cll}
\hline No & Siklus & Persentase Hasil Pengamatan \\
\hline 1. & Pra Siklus & $44,45 \%$ \\
2. & Siklus 1 & $80,56 \%$ \\
3. & Siklus 2 & $100 \%$ \\
\hline
\end{tabular}

Dari uraian kegiatan diatas, dapat digambarkan dengan diagram sebagai berikut:

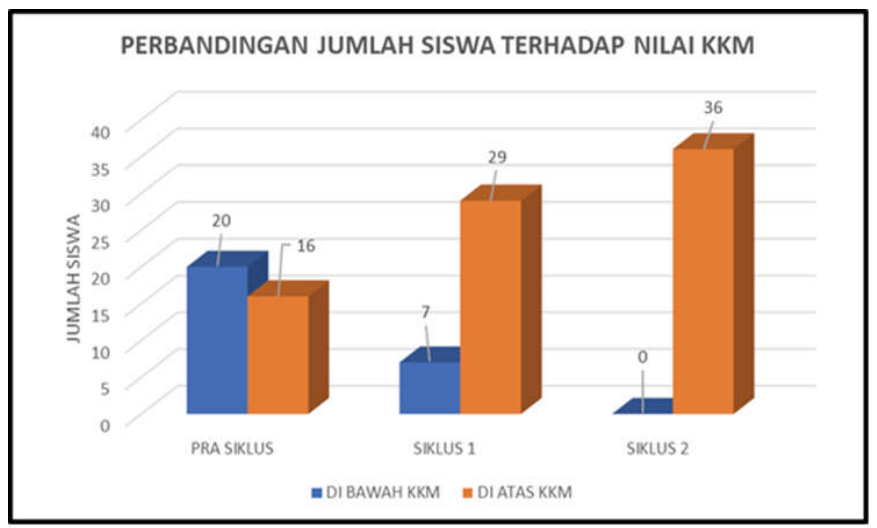

Gambar 4: Diagram Perbandingan nilai hasil belajar

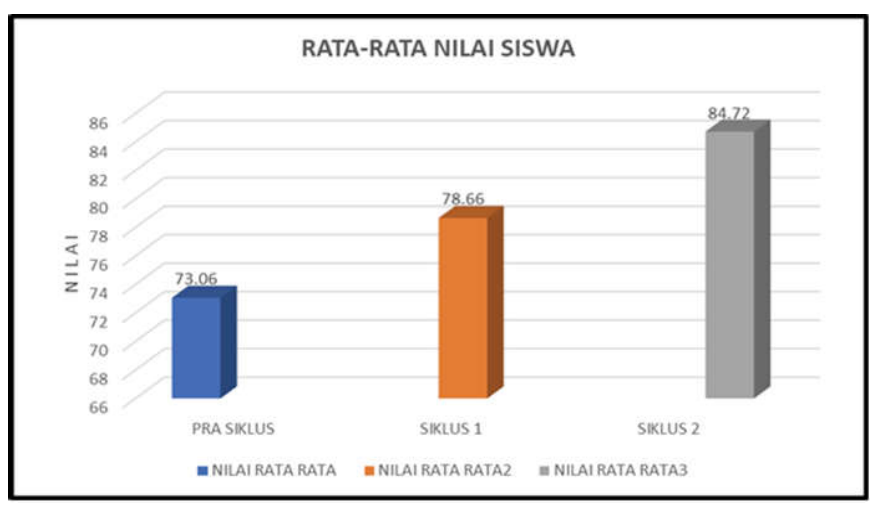

Gambar 5. Diagram rata-rata nilai pada pra silus, siklus 1 dan siklus 2

Dari hasil olahan data diatas, kenaikan nilai rata-rata dari pra siklus ke siklus 1 sebesar $7,6 \%$ dan dari siklus 1 ke siklus 2 sebesar 7,6\%. Selanjutnya dari pra siklus ke siklus 2 mengalami peningkatan sebesar 15,9 \%. Artinya Gerakan Literasi Sekolah yang didukung oleh warga sekolah terdapat pengaruh yang signifikan.

Dalam melaksanakan GLS di SMA 67, peran guru mata pelajaran Sejarah Indonesia memiliki peran penting. Guru melaksanakan pembelajaran, menggunakan pendekatan yang komprehensif dan progresif, sekaligus melakukan penelitian untuk mendapatkan gambaran tentang manfaat gerakan literasi sekolah terhadap hasil belajar siswa pada mata pelajaran nasional Indonesia. GLS dalam sepekan terdapat tiga kali kegiatan, setiap kegiatannya waktunya adalah 15 menit sebelum pembelajaran dimulai. Selain itu dijadwalkan juga satu kali dalam sepekan 45 menit diakhir pembelajaran.

Untuk menghilangkan kejenuhan dalam pelaksaan literasi disekolah, maka sekolah mensiasati dengan variasi yaitu dengan perpaduan pengembangan keterampilan reseptif maupun produktif. Keterampilan reseptif dimaksudkan adalah suatu kemampuan siswa untuk memahami bahasa lisan yang didengar atau dibaca saat siswa berada di dalam kelas, baik saat mendengarkan penjelasan guru atau mendengarkan temannya saat berdiskusi. Kemampuan produktif yaitu suatu kemampuan siswa dalam berbahasa menyampaikan informasi atau gagasan baik secara lisan maupun tulisan.

GLS mengutamakan bahasa, karena dengan bahasa menjadi sarana untuk menyampaikan maksud terhadap orang lain. "Bahasa adalah kunci pokok kehidupan, karena dengan bahasa manusia dapat 
berinteraksi dengan sesamanya dan bahasa merupakan sumber daya bagi kehidupan bermasyarakat" (Nurhasanah, 2017: 88).

GLS menjadi kegiatan yang inovatif pada saat guru membacakan buku yang disimak oleh warga sekolah (kepala sekolah, peserta didik, para guru, dan tenaga kependidikan) akan mendapatkan pengetahuan baru setelah adanya kegiatan literasi.

Selain variasi diatas, dilakukan juga kegiatan membaca mandiri dengan target yang ditentukan sekolah. Judul buku bacaan diserahkan pada pilihan masing-masing siswa, namun judul buku tersebut sesuai dengan ketentuan sekolah. Ketentuannya adalah buku tersebut mengandung unsur edukatif, yaitu sesuai dengan konteks pendidikan atau membaca buku nonteks pelajaran dapat berupa pengetahuan umum, kegemaran, minat khusus.

Sekolah sebagai institusi pendidikan menjadi tempat kegiatan literasi yang akan melahirkan berbagai kreativitas dan inovasi dari warga sekolah. Guru sebagai ujung tombak dalam kegiatan literasi berhadapan langsung dengan siswa memiliki peran yang sangat setrategis atas perkembangan karakter dan budi pekerti siswa. Oleh karena itu penulis sebagai bagian dari guru dalam kegiatan gerakan literasi sekolah mencoba untuk mendesain penelitian berkaitan dengan gerakan literasi sekolah pada saat proses pembelajaran dalam kelas. Penulis memandang bahwa gerakan literasi sekolah dapat membuka wawasan, dan pengalaman siswa pada setiap materi bacaan.

\section{SIMPULAN DAN SARAN}

Dari latar belakang dan pembahasan dapat disimpulkann bahwa GLS dapat memberikan motivasi siswa dalam mengembangkan potensinya selama mengikuti proses pembelajaran di sekolah. GLS pada mata pelajaran sejarah Indonesia memiliki pengaruh signifikan terhadap hasil belajar siswa, terjadi peningkatan nilai dari kegiatan pra siklus sampai dengan kegiatan siklus 2. Peran guru mata pelajaran pada gerakan literasi sangat berpengaruh terhadap motivasi siswa. Aktivitas guru dalam pelaksanaan literasi adalah memberikan pendampingan dan mengawasi pelaksanaan literasi pada saat mata pelajaran berlangsung. Guru disamping memberikan pendampingan juga mengambil peran sebagai fasilitator, motivator, dan inspirator bagi siswa dalam kegiatan literasi agar dapat membentuk mental dan karakter siswa dari bahan literasi yang dilakukan.

GLS dapat berlangsung dengan baik jika mendapat dukungan dari warga sekolah diantaranya siswa, pendidik, tenaga kependidikan, wali siswa, komite sekolah dan pengawas sekolah. GLS yang dilaksanakan dengan menyenangkan dan partisipatif dapat meningkatkan hasil belajar siswa pada mata pelajaran sejarah Indonesia.

Agar gerakan literasi sekolah dapat berlangsung dengan baik, dibutuhkan suatu program yang terjadwal sehingga mendapat dukungan dari warga sekolah. Dalam gerakan literasi sekolah diperlukan sarana yang dapat meningkatkan motivasi dan kreativitas siswa untuk mengembangkan hasil literasi. Seperti perpustakaan yang nyaman dengan buku-buku bacaan yang menarik, audio visual untuk mengembangkan bakat siswa dalam ajang kreativitas. Kegiatan literasi sekolah hendaknya didokumentasikan sebagai bagian dari tindakan yang dapat mengukur dari setiap kegiatan tahunan agar kegiatan tersebut menjadi lebih baik dan bermakna.

\section{PUSTAKA ACUAN}

Direktorat Jendral Pendidikan Dasar dan Menengah. Desain Induk Gerakan Literasi Sekolah. Jakarta: Ditjen Dikdasmen, 2016.

Musfiqon, Jurnal Pendidikan, Teori, Penelitian, dan Pengembangan, 3(11), 1488-1498. Metodologi Penelitian Pendidikan. Jakarta: Prestasi Pustaka.2012.

Hasanuddin, Jurnal Al Hikmah, Dominasi Pendidikan Barat, Vol. XV Nomor 2/2014: 170

La Hewi, Muh. Shaleh, Jurnal Tunas Siliwangi: Penguatan Peran Lembaga Paud Untuk The Programme for International Student Assesment vol. 6, no. 2, Oktober 2020: 64

Nurhasanah, Nina. Jurnal Esa Unggul, Peranan Bahasa Sebagai Mata Pelajaran Wajib di Indonesia Vol.2, No.2 Februari $2017: 88$

Soedarso. Speed Reading Sistem Membaca Cepat dan Efektif. Jakarta: Gramedia Pustaka Utama, 2002.

Sugiyono, Metode Penelitian Kuantitatif \& Kualitatif dan R\&D. Bandung, Alfabeta, 2011.

Suryanegara, Ahmad Mansyur, Api Sejarah. Jilid 1, Bandung. Surya Dinasti, 2015.

Tarigan, Henry Guntur. Membaca: Sebagai Suatu Ketrampilan Bahasa. Bandung. Angkasa, 2008. 